\title{
Misguided urinary catheter: an uncommon complication of a common solution
}

\author{
Vinod Kumar, Ajay Hegde, Rajesh Parameshwaran Nair, Lakshman I Kongwad
}

Department of Neurosurgery, Kasturba Medical College, Manipal, India

Correspondence to Dr Ajay Hegde,

dr.ajayhegde@gmail.com

Accepted 2 April 2018

\section{DESCRIPTION}

A 61-year-old man was wheeled in to our emergency triage bleeding profusely from his mouth and nose in an unconscious state. His Glasgow Coma Scale was 7 and was intubated for airway safety. A failed anterior nasal packing was followed by insertion of a Foley urinary catheter through the right nostril to secure posterior nasal packing and haemostasis. CT of the brain following nasal packing showed diffuse traumatic subarachnoid haemorrhage and basifrontal contusions with multiple fractures of the anterior cranial fossa, cribriform plate including the frontal sinus. Multiple specs of air in the frontal lobe was initially mistaken as pneumocephalus (Hounsfield unit -971) (figure 1). The Foley catheter had inadvertently found its way to the brain through the cribriform plate, and the bulb was inflated just above the defect (figure 2). The catheter was deflated and removed soon after imaging. The patient underwent a right frontotemporoparietal craniectomy with basal repair for his severe head injury. The patient had a prolonged hospital stay and finally succumbed to severe head injury.

Facial trauma is commonly associated with fractures of the anterior skull base, frontal sinus, cribriform plate, ethmoid air cells and the sphenoid sinus, with profuse bleeding from the oro-nasal orifices. Although posterior nasal packing is contraindicated in such patients, it is often the first line of management in an emergency setting prior to arterial ligation/embolisation. ${ }^{1}$ Urinary catheters are the most common balloon catheters used for this purpose. While cranial migration

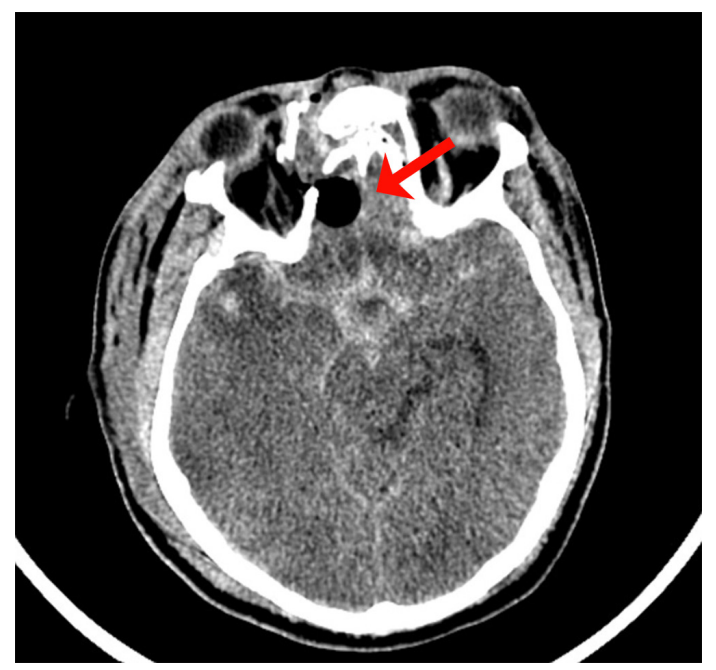

Figure $1 \mathrm{CT}$ scan axial view showing the inflated Foley bulb, which was mistaken as pneumocephalus.

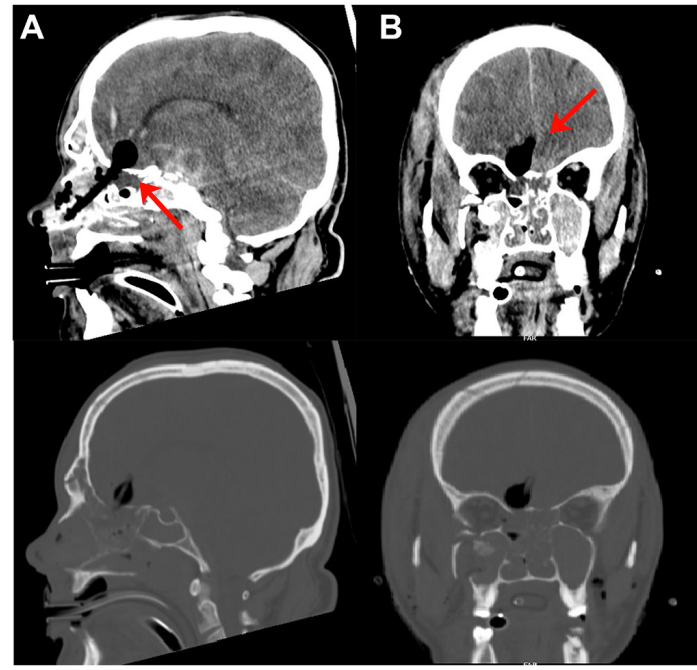

Figure 2 CT of the brain with fractures of the cribriform plate, ethmoid sinus and misguided Foley catheter with inflated bulb lying just above the cribriform plate with their corresponding bone windows. (A) sagittal view and (B) coronal view.

of nasogastric tube is not an uncommon occurrence, only five cases of accidental urinary catheter passage into the intracranial cavity have been reported. ${ }^{2}$ It is usually associated with a high mortality of $>50 \%$ and complications such as intraparenchymal haemorrhage, hemiparesis, meningitis and cerebrospinal fistula. ${ }^{3}$ In the event of an absolute necessity to introduce these endonasal apparatus, it should be under direct or endoscopic visualisation confirmed with fluoroscopy. Thus, fractures of the anterior cranial fossa are a contraindication for endonasal procedures and should be dealt with extreme caution.

Learning points

- Anterior cranial fossa and cribriform plate fractures are a contraindication for posterior nasal packing

- Passage of endonasal tubings into the brain parenchyma is associated with high mortality and complications such as haemorrhage, meningitis and Cerebrospinal Fluid (CSF) fistulas.

Contributors VK was responsible for the diagnosis. AH was responsible for the writeup. RPN was responsible for the image editing. LIK was responsible for the review.

Funding The authors have not declared a specific grant for this research from any funding agency in the public, commercial or not-for-profit sectors. 


\section{Images in...}

\section{Competing interests None declared.}

\section{Patient consent Obtained.}

Provenance and peer review Not commissioned; externally peer reviewed.

(C) BMJ Publishing Group Ltd (unless otherwise stated in the text of the article) 2018. All rights reserved. No commercial use is permitted unless otherwise expressly granted.

\section{REFERENCES}

1 Başkaya MK. Inadvertent intracranial placement of a nasogastric tube in patients with head injuries. Surg Neurol 1999:52:426-7.

2 Veeravagu A, Joseph R, Jiang B, et al. Traumatic epistaxis: Skull base defects, intracranial complications and neurosurgical considerations. Int I Surg Case Rep 2013;4:656-61.

3 Fletcher SA, Henderson LT, Miner ME, et al. The successful surgical removal of intracranial nasogastric tubes. J Trauma 1987;27:948-52.

Copyright 2018 BMJ Publishing Group. All rights reserved. For permission to reuse any of this content visit http://group.bmj.com/group/rights-licensing/permissions.

BMJ Case Report Fellows may re-use this article for personal use and teaching without any further permission.

Become a Fellow of BMJ Case Reports today and you can:

- Submit as many cases as you like

- Enjoy fast sympathetic peer review and rapid publication of accepted articles

- Access all the published articles

Re-use any of the published material for personal use and teaching without further permission

For information on Institutional Fellowships contact consortiasales@bmjgroup.com

Visit casereports.bmj.com for more articles like this and to become a Fellow 